\title{
MODEL KOMUNIKASI ANTARBUDAYA MAHASISWA MUSLIM THAILAND DALAM PROSES AKULTURASI BUDAYA DI KABUPATEN JEMBER
}

\author{
Clara Sinta Pratiwi \\ Komunikasi dan Penyiaran Islam Pascasarjana IAIN Jember \\ pratiwiclara274@gmail.com
}

Diunggah 01 September / Direvisi 01 Oktober / Diterima 05 November 2020

\begin{abstract}
Abstrac: Thai Muslim students are spread across various universities in Jember. In interacting as a minority community, Thai Muslim students have made various adaptations to the dominant culture of Jember which is known as phandalungan culture. It is caused by the majority of people in Jember are inhabited by people with Madurese and Javanese cultural backgrounds. The intercultural communication process of Thai Muslim students in the process of acculturation in Jember can be seen by the intercultural communication model by William $B$. Gudykunts and Alo Liliweri's tori of cultural acculturation. Qualitative methods with phenomenological studies reveal that the communication model of Thai Muslim students in the process of cultural acculturation in Jember by adapting seven elements of universal culture. In addition, the students have acculturation and produce various models of acculturation, namely assimilation, integration, marginalization, and separation. Communication of Thai Muslim students in dealing with the dominant culture in Jember Regency by first experiencing a process of cultural shock. The process of cultural shock is a process where students experience a new cultural clash that is different from their original culture.
\end{abstract}

Keywords: Intercultural Communication Model, Thai Muslim Students, Cultural Acculturation

Korespondensi: Clara Sinta Pratiwi

IAIN Jember

pratiwiclara274@gmail.com 


\section{A. PENDAHULUAN}

Hubungan yang semakin tinggi dan erat antar manusia dan masyarakat dari berbagai negara akan berpengaruh terhadap berbagai aspek kegiatan manusia, salah satunya di bidang pendidikan. Hal ini menyebabkan fenomena meningkatnya pertukaran pelajar maupun pelajar asing yang menempuh pendidikan secara penuh di suatu negara. Hal tersebut juga terjadi di Indonesia, dimana Indonesia bukan hanya mengirimkan mahasiswa ke luar negeri namun juga menjadi tujuan bagi pelajar asing untuk menuntut ilmu. Indonesia adalah salah satu negara yang memberikan kemudahan bagi pelajar asing yang hendak melakukan studi di Negara Indonesia. Pernyataan ini dibuktikan oleh banyaknya jumlah mahasiswa asing yang menyebar diseluruh universitas di Indonesia.

Di kabupaten Jember, terdapat beberapa perguruan tinggi yang menerima mahasiswa asing untuk belajar. Mahasiswa asing yang belajar di Jember tersebar dibanyak perguruan tinggi negeri dan swasta. Sederetan perguruan tinggi itu antara lain Universitas Negeri Jember, Institut Agama Islam Negeri Jember, dan Universitas Muhammadiyah Jember. Mahasiswa asing yang berkuliah di perguruan tinggi di kabupaten Jember berasal dari berbagai macam Negara, salah satunya berasal dari Thailand. Mahasiswa ini masuk ke perguruan tinggi tersebut melalui dua jalur, yakni melalui jalur beasiswa dan jalur dari Ikatan Badan Alumni (IBA) Thailand. ${ }^{1}$

Kabupaten Jember menjadi kota tujuan para mahasiswa muslim Thailand melanjutkan jenjang perguruan tinggi dengan beragam pandangan. Disamping sebagai momen untuk menambah wawasan dan pengalaman baru, rupanya kabupaten jember dalam pandangan mereka memiliki identitas budaya beragam dan lingkungan yang ramah. ${ }^{2}$ Tentu saja pengetahuan tentang ini mereka dapatkan sebelumnya dari para senior-senior mereka yang sudah lebih dulu menetap dan belajar di perguruan tinggi yang tersebar di kabupaten Jember.

Selanjutnya mahasiswa Thailand yang memilih untuk melakukan studi di kabupaten Jember sudah pasti akan mengalami proses adaptasi budaya dan berkomunikasi antarbudaya dengan mahasiswa dan masyarakat lokal. Adaptasi budaya itu secara umum adalah bentuk pembiasaan diri terhadap budaya baru yang

\footnotetext{
${ }^{1}$ Hery Bambang Cahyono, Hambatan Komunikasi Antarbudaya Mahasiswa Thailand di Jember. Jurnal Ilmu Komunikai Mediakom Vol.1 No.2 2018.

${ }^{2}$ Hasil wawancara terhadap salah satu mahasiwa muslim Thailand yang belajar di Univ. Muhammadiyah jember dan IAIN jember.
} 
berbeda dengan budaya asal. Ketika mahasiswa asing melakukan studi di Indonesia, maka sudah dapat dipastikan mereka akan mengalami proses pembiasaan diri dengan budaya Indonesia. Hal ini terjadi karena setiap negara memiliki budaya masing-masing dan tidak sama satu sama lain. ${ }^{3}$ Budaya yang berkembang dan dominan di kabupaten Jember adalah budaya Madura dan Jawa. Sehingga kota Jember terkenal dengan kota phandalangan.

Komunikasi antar budaya terjadi ketika anggota dari satu budaya tertentu memberikan pesan kepada anggota dari budaya lain. Tepatnya komunikasi antarbudaya selalu melibatkan interaksi antara orang-orang dimana persepsi budaya dan sistem simbolnya cukup berbeda dalam suatu komunikasi. ${ }^{4}$ Semua pemain dalam komunikasi antarbudaya haruslah memiliki pengertian ketika saling berinteraksi dan berkomunikasi. Kesalahpahaman sering terjadi dalam proses komunikasi antar budaya. Proses trial and error kerap terjadi dalam proses akulturasi. Hal tersebut dapat dikurangi bila sedikitnya para pemain mengetahui bahasa dan perilaku budaya orang lain, mengetahui prinsip-prinsip komunikasi antar budaya, dan mempraktikkannya dalam berkomunikasi.

Dalam proses komunikasi yang dilakukan oleh mahasiswa Thailand, tidak jarang juga perbedaan budaya memunculkan berbagai hambatan, seperti kendala bahasa dan culture shock atau gegar budaya. Gegar budaya adalah istilah psikologis untuk menggambarkan keadaan dan perasaan seseorang menghadapi kondisi lingkungan sosial budaya yang berbeda. ${ }^{5}$ Komunikasi antarbudaya yang dilakukan oleh mahasiswa asing takkan semudah berkomunikasi seperti biasanya, terdapatnya perbedaan budaya diantara mahasiswa asing dan masyarakat Indonesia, menjadikan komunikasi yang terjadi diantara mahasiswa asing dan masyarakat pribumi tidaklah selalu efektif.

Dalam interaksi antar budaya kerap terjadi proses akulturasi. Hal ini disebabkan adanya perbedaan budaya yang dialami sebuah kelompok atau individu dalam sebuah komunitas baru. Akulturasi dapat diartikan sebagai suatu proses sosial yang timbul bila suatu kelompok manusia dengan kebudayaan tertentu

\footnotetext{
${ }^{3}$ Tinka Fakhriana, Adaptasi Budaya Pada Mahasiswa Asing Di Indonesia (Studi Fenomenologi Pada Mahasiswa Asing Di Kota Bandung). Jurnal Ilmu Komunikasi dan Bisnis Vol.4.No.1.2018

${ }^{4}$ Larry A. Samovar, Richard E. Porter, dan Edwin R.McDaniel, Komunikasi Lintas Budaya.(Jakarta: Salemba Humanika, 2010), hal.13

${ }^{5}$ Ngalimun, Komunikasi Antarbudaya. (Yogyakarta: Pustaka Pelajar, 2018). hal.60
} 
dihadapkan dengan unsur-unsur kebudayaan asing dengan sedemikian rupa, sehingga lambat laun diterima dan diolah kedalam kebudayaan sendiri tanpa menghilangkan kepribadian kebudayaan itu sendiri. ${ }^{6}$ Salah satu contoh akulturasi budaya adalah adanya pembagian uang yang dibungkus kedalam amplop amplop cantik dalam perayaan hari raya Idul Fitri bagi umat muslim di Indonesia. Sejatinya tradisi tersebut merupakan tradisi Tionghoa yang disebut sebagai angpau.

Dengan berbagai tradisi dan kebudayaan yang berbeda, ketika mahasiswa Thailand masuk ke kampus, maka proses akulturasipun berlangsung, Proses akulturasi akan terus berlangsung selama imigran melakukan kontak langsung dengan sosio-budaya pribumi. ${ }^{7}$ Mahasiswa Thailand dituntut untuk dapat menyesuaikan diri agar dapat diterima dan berinteraksi. Dalam hal ini, mahasiswa dituntut tidak hanya untuk kebutuhan hidup di sekitar kampus saja, namun juga dalam hal studi.

\section{B. PEMBAHASAN}

\section{Mahasiswa Muslim Thailan di Kabupaten Jember}

1) Mahasiswa Muslim Thailand di Universitas Negeri Jember

Universitas Jember mempunyai tugas pokok adalah untuk menyelenggarakan pendidikan tinggi dan memberikan pendidikan berdasarkan kebudayaan bangsa Indonesia dengan cara ilmiah yang meliputi pendidikan, penelitian, dan pengabdian kepada masyarakat dalam mengembangkan kemampuan serta meningkatkan mutu kehidupan dan martabat bangsa Indonesia dalam upaya mewujudkan tujuan nasional. Pada dasarnya, Universitas Jember memiliki lima fungsi diantaranya melaksanakan dan mengembangkan pendidikan, melakukan penelitian untuk pengembangan ilmu pengetahuan dan tekhnologi, melaksanakan pelayanan masyarakat, melaksanakan pembinaan sivitas akademika dan hubungannya dengan lingkungan, dan melakukan pelayanan administrasi. ${ }^{8}$

Para pendahulu Universitas Jember telah memberikan landasan filosofi dalam pengembangan lembaga berupa sesanti "Karya Rinaras Ambuka Budhi,

\footnotetext{
${ }^{6}$ Koentjaningrat, Pengantar Ilmu Antropologi, (Jakarta: Rineka Cipta, 2015). hal.202

${ }^{7}$ Deddy Mulyana dan Djalaluddin Rakhmat, Komunikasi Antarbudaya Panduan Berkomunikasi dengan Orang-orang Berbeda Budaya, (Bandung : PT Remaja Posdakarya, 2010 ), hal.146

${ }^{8} \mathrm{Htpp}: / /$ www.unej.ac.id/tentang/\#motto (Juni,2020)
} 
Gapura Mangesti Aruming Bawana". Sesanti tersebut bermakana Karya Rinaras Ambuka Budhi merupakan tekad Universitas Jember untuk menata diri, selalu kerja selaras, serasi, dan seimbang yang dilandasi iman dan taqwa untuk menerima perkembangan IPTEKS. Gapura Mangesti Aruming Bawana merupakan sasaran kinerja Universitas Jember. Untuk menghasilkan sarjana yang sujana sebagai manusia seutuhnya yang pengabdiannya di masyarakat selalu membawa keharuman bangsa dan Negara, kemakmuran, kesejahteraan, dan perdamaian umat manusia. Selain sesanti tersebut dalam rangka memberikan arah untuk meningkatkan kualitas masukan, proses, dan keluaran secara berkelanjutan, UNEJ telah merumuskan kebijakan mutu akademik. Intisari dari kebijakan mutu akademik tersebut adalah UNEJ akan selalu mengutamakan kualitas (Quality First). ${ }^{9}$

Sesuai dengan motto dan fungsi Universitas jember tersebut, selalu diadakan inovasi-inovasi agar kampus UNEJ selalu menjadi kampus terdepan. Salah satunya adalah program internasionalisasi pendidikan dengan mendatangkan mahasiswa asing untuk belajar dan menimba ilmu di UNEJ. Mahasiswa asing terbanyak saat ini yang berada di kampus UNEJ adalah mahasiswa yang berasal dari daerah Pattani (Thailand Selatan).

Para mahasiswa ini masuk ke UNEJ melalui jalur beasiswa. Mereka mengurus segala keperluan melalui sebuah lembahga yang disebut sebagai Lembaga Majelis Pattani. Para calon mahasiswa hanya tinggal menyiapkan diri dan mental untuk segera merantau ke negeri Indonesia untuk melanjutkan studi, sebab segala kebutuhan dan hubungan dengan kampus sudah ditangani oleh pihak Lembaga Majelis Pattani.

Terdapat beberapa alasan mengapa para mahasiswa muslim Thailand memilih Indonesia sebagai tempat melanjutkan studi, diantaranya karena biaya yang relatif murah jika dibandingkan dengan kampus-kampus yang berada di negeri lain, hal ini disebabkan karena mata uang rupiah yang lebih rendah jika dibandingan dengan mata uang di Negara bagian Asia Tenggara atau bahkan di luar itu. Kemudian alasan lain mengapa mereka memilih Indonesia sebagai tempat melanjutkan studi adalah karena kualitas output yang dihasilkan, kualitas sistem akademik yang baik, dan keramahan para warga Indonesia.

9 Htpp ://www.unej.ac.id/tentang/\#Fungsi (Juni,2020) 
2) Mahasiswa Muslim Thailand di Universitas Muhammadiyah Jember

Universitas Muhammadiyah Jember adalah salah satu Perguruan Tinggi milik Persyarikatan Muhammadiyah, didirikan berdasarkan Piagam Pendirian Perguruan Tinggi Muhammadiyah Nomor : 047/III-JTM.81/81 tertanggal 1 September 1981 dan disetujui oleh Pemerintah berdasar Surat Keputusan Menteri Pendidikan dan Kebudayaan RepublikIndonesia Nomor :0172/Q/1982 tertanggal 10 Mei 1982. Pada awalnya, pendidikan yang diselenggarakan adalah Fakultas Hukum, Fakultas Keguruan dan Ilmu Pendidikan, serta fakultas Pertanian. Masing-masing mendapatkan status Terdaftar dari Departemen Pendidikan dan Kebudayaan RI. Dalam rangka memenuhi permintaan masyarakat, pada 1982 dibuka Fakultas Ekonomi. Selanjutnya pada tahun 1983 dibuka Fakultas Ilmu Sosial dan Ilmu Politik. Selanjutnya Pada tahun 1984 dibuka Fakultas Teknik. pada saat berusia 3 tahun, Universitas Muhammadiyah Jember sudah memiliki 6 fakultas. ${ }^{10}$

Dalam rangka meningkatkan kualitas, perhatian dipusatkan pada pembinaan akademik, sarana dan prasarana, laboratorium, dan perpustakaan. Untuk meningkatkan kualitas tenaga pengajar, ditempuh upaya mendorong dan menugaskan dosen untuk pendidikan lanjutan pada Program Pendidikan S2 dan S3, baik di dalam negeri maupun di luar negeri. Disamping itu, Universitas Muhammadiyah Jember juga melakukan kerjasama dengan menerima pelajar asing untuk berkuliah. Mahasiswa tersebut berasal dari berbagai Negara seperti Malaysia, Brunei Darrusalam, dan Thailand Selatan (Pattani).

Saat ini mahasiswa asing terbanyak berasal dari Negara Pattani (Thailand Selatan). Jumlahnya sebanyak 32 orang yang tersebar di berbagai fakultas dan jurusan.

Mahasiswa muslim Thailand bisa melanjutkan studi di Universitas Muhammadiyah Jember melalui Badan Alumni (BA). Mereka yang berkuliah di Universitas Muhammadiyah Jember mendapatkan beasiswa dan mendapatkan bebas visa. Karena menggunakan visa pelajar, mereka harus memperbaharui visa setahun sekali. Dalam memperbaharui visa, para mahasiswa ini di koordinir oleh pihak kampus.

10http://www.unmuhjember.ac.id/id/tentang-umjember/selayang-pandang/sejarah-universitas.html (Juni 2020) 
Saat awal sampai di Jember, para mahasiswa mendapatkan kursus kebahasaan selama kurang lebih tiga bulan dari pihak kampus. Hal ini untuk mengantisipasi kesulitan mahasiswa dalam berkomunikasi dan memahami mata kuliah selama di kelas. Kebijakan kampus ini sangat membantu para mahasiswa muslim Thailand, sebab meski Indonesia dan Thailand Selatan masih dalam satu rumpun melayu, logat dan ketata bahasaan yang digunakan berbeda.

Para mahasiswa muslim Thailand yang berkuliah saat ini memiliki dua organisasi perkumpulan yakni HMPI (Himpunan Mahasiswa Pattani Indonesia) dan IMASEJ (Ikatan Mahasiswa Selatan Thailan Jember). Organisasi adalah organisasi yang anggotanya terdiri dari seluruh mahasiswa muslim Thailand yang berkuliah di Jember. Sedangkan IMASEJ adalah organisasi yang anggotanya hanya berasal dari mahasiswa muslim Thailand yang berkuliah di Universsitas Muhammadiyah Jember. Organisasi ini dibentuk untuk menyelenggarakan berbagai kegiatan kemahasiswaan dalam rangka membina dan mempersiapkan generasi intelektual islamis.

Organisasi ini dibentuk pada 09 Desember 2015 dan pada tanggal itu ditetapkan sebagai hari jadi IMASEJ meskipun organisasi ini baru diresmikan pada 26 Maret 2016. Adapun visi organisasi ini adalah Mewujudkan cita-cita dalam menjalankan persaudaraan dan kesatuan. Mempersiapkan insan mahasiswa yang mandiri, aspiratif, berkualitas, independen serta berguna bagi masyarakat, agama dan bangsa. Mahasiswa muslim Thailand ini berharap kelak menjadi lulusan yang berkualitas dan bermanfaat bagi masyarakat disekitarnya kelak. Sehingga perjuangan mereka dalam menuntut ilmu hingga ke negeri tetangga tidak menjadi sia-sia.

Sesuai dengan visi organisasi, misi organisasi IMASEJ adalah Meningkatkan intelektualitas anggota agar menjadi manusia yang berakhlak dan bertaqwa kepada Allah SWT, Mengembangkan potensi kreatif, keilmuan, dan sosial demi masyarakat agama dan bangsa, menumbuhkan kesadaran seluruh mahasiswa betapa pentingnya kerja keras dalam proes mengejar cita-cita, dan memperkuat ukhuwah Islamiah sesama umat Islam dan umat manusia.

3) Mahasiswa Muslim Thailand di Institut Agama Islam Negeri Jember

Institut Agama Islam Negeri Jember adalah Perguruan Tinggi Agama Islam yang berlokasi di Jl. Mataram No.1, Karang Mulwo, Mangli, Kecamatan Kaliwates, 
Kabupaten Jember, Jawa Timur. Perguruan tinggi ini cukup termasyhur dikabupaten Jember. Perguruan ini disahkan dengan keluarnya Surat Keputusan Presiden no 11 pada tahun 1997 tentang pendirian Sekolah Tinggi Agama Islam Negeri (STAIN) Jember. ${ }^{11}$

Seiring dengan peralihan tersebut, IAIN Jember terus melakukan upayaupaya dalam mengembangangkan perguruan tinggi untuk meningkatkan kecerdasan, harkat, dan martabat bangsa dengan menghasilkan lulusan yang memiliki wawasan luas, terbuka, memiliki kemampuan manajemen, dan professional sesuai tuntutan zaman dan kebutuhan masyarakat. Salah satu upaya yang terus dilakukan adalah dengan melakukan internasionalisasi pendidikan melalui penerimaan mahasiswa asing yang berasal dari Thailand Selatan untuk melakukan studi di IAIN Jember. Saat ini jumlah mahasiswa yang tercatat melakukan studi di IAIN Jember berjumlah 39 orang.

Jember menjadi tujuan belajar para calon mahasiswa muslim Thailand karena menurut mereka kota Jember adalah kota yang tidak terlalu ramai seperti Malang, Surabaya, atau daerah kota lainnya. Dan di jember terdapat beberapa perguruan tinggi yang cukup terkenal dan berkualitas. Warga kota jember juga menurut mereka terkenal ramah dengan gaya hidup yang tidak terlalu mewah.

Seluruh mahasiswa baru IAIN diwajibkan untuk masuk Ma'had atau asrama kampus selama satu tahun termasuk mahasiswa asing. Jadi para mahasiswa muslim Thailand yang tercatat sebagai mahasiswa baru wajib mengikuti aturan kampus untuk tinggal di asrama selama satu tahun. Disana mereka mulai beradaptasi dengan mahasiswa baru lainnya yang berasal dari berbagai daerah.

Banyak kesulitan yang dihadapi mahasiswa muslim Thailand selama ada di asrama, mulai dari bahasa yang digunakan para penghuni asrama lainnya. Para penghuni asrama biasanya saling berkomunikasi menggunakan bahasa daerah mereka seperti bahasa madura atau jawa sebab mayoritas penghuni asrama adalah orang Madura dan Jawa.

Para mahasiswa muslim Thailand di IAIN Jember mengakui jika kurikulum perkuliahan di IAIN lebih diminati dan menantang disbanding dengan kurikulum mereka di negeri asal. Hal ini dikarenakan kurikulum perkuliahan di

${ }^{11}$ http://www.iain-jember.ac.id/page/detail.sejarah-iain-jember.html (Juni, 2020) 
Thailand masih menggunakan sistem dimana dosen memegang kendali penuh akan jalannya kondisi kelas. Dosen memberi materi dan memberi tugas. Sedangkan di Indonesia dosen hanya sebagai pengarah saja. Diskusi lebih diutamakan. Hal inilah yang menarik minat mereka. Para mahasiswa dituntut untuk mampu melakukan presentasi materi dan berdiskusi mengenai materi yang telah di presentasikan.

\section{Teori Akulturasi Empat Kali Lipat}

Definisi akulturasi mengenal istilah fourfold model (model empat kali lipat) akulturasi adalah model bilinear yang mengategorikan strategi akulturasi dalam dua dimensi : (1) dimensi yang berkaitan dengan retensi atau penolakan terhadap budaya asli minoritas individu atau budaya asli (apakah dianggap bernilai untuk mempertahankan identitas dan karakteristik seseorang), dan (2) dimensi yang menyangkut adopsi budaya atau penolakan budaya kelompok dominan atau tuan rumah (apakah dianggap bernilai untuk menjaga hubungan dengan masyarakat yang lebih besar). Dari sini muncul empat strategi akulturasi : 12

a) Asimilasi, terjadi ketika individu mengadopsi norma budaya yang dominan atau tuan rumah melebihi budaya asli mereka.

Proses asimilasi yang terjadi pada mahasiswa muslim Thailand adalah dalam menunjuk benda ketika berbicara kepada orang yang jauh lebih tua. Bila kebiasaan yang awalnya mereka sering lakukan di tanah kelahiran adalah menunjuk menggunakan jari telunjuk meskipun yang diajak berbicara lebih tua, maka ketika berada di lingkungan Jember, para mahasiswa muslim Thailand menunjuk suatu benda mengikuti normasosial yang sering dilakukan oleh masyarakat jember yakni menggunakan jempol kanan dengan sisa jari tersedekap rapi.

b) Separasi, atau pemisahan, terjadi ketika individu menolak budaya dominan atau budaya tuan rumah yang tidak mendukung melestarikan budaya asal mereka. Pemisahan budaya sering difasilitasi oleh penempatan imigrasi ke kantongkantong tertentu.

Hal ini banyak terjadi dari berbagai aspek kehidupan mahasiswa muslim Thailand yang menempuh studi di Jember. Hal ini didukung dengan adanya

\footnotetext{
${ }^{12}$ Alo Liliweri, Prasangka,Konflik, dan Komunikasi Antar Budaya. (Jakarta : Prenada Media Grup,2018). Hal.267
} 
pemisahan organisasi yang mereka ikuti. Para mahasiswa muslim Thailand memiliki organisasi tersendiri yang hanya beranggotakan para mahasiswa uslim Thailand yang tersebar di wilayah kabupaten Jember. Organisasi ini bernama organisasi HMPI (Himpunan Mahasiswa Muslim Patani Indonesia) dan IMASEJ (Ikatan Mhasiswa Selatan Thailand Jember).

Kegiatan yang diadakan adalah kegitan untuk tetap melestarikan budaya asal yang dimiliki oleh mahasiswa muslim Thailand. Sedang untuk kegiatan yang berhubungaan dengaan budaya-budaya yang berkembang di daerah imigran, mahasiswa muslim Thailand hanya sebagai pengikut di berbagai organisasi lain, tanpaa ikut andil secara mendalam.

c) Integrasi, terjadi ketika individu mampu mengadopsi norma budaya yang dominan atau budaya tuan rumah sambil mempertahankan budaya asal mereka.

Banyak budaya-budaya asal dan dominan yang telah masuk dalam kehidupan kesehaarian para mahasiswa muslim Thailand yang menempuh studi di Jember. Jember yang dominan dihuni oleh orang jawa dan Madura menciptakan budaya phandalungan.

d) Marginalisasi, terjadi ketika individu menolak budaya asal mereka dan budaya tuan rumah yang dominan.

Tentang hal ini hamper tidak peneliti temukan terjadi pada maahasiswa muslim Thailand. Yang peneliti temukan adaalah penolakan terhadap budaya dominan. Seperti budaya kampus yang sering ditemui oleh mahasiswa muslim Thailand bahwa para mahasiswa terbiasa sungkem kepada dosen pengajar di kelas. Baik itu mahasiswa putri maupun putra, baik dosen yang mengajar putri maupun putra, baik dosen yang mengajar sudah sepuh ataupun belum.

Hal ini sulit mereka terima dikarenakaan para mahasiswa muslim Thailand tidak memiliki budaya sungkem jika guru mereka bukan mahrom. Hal itu sudah lumrah dilakukan di Negara asal mereka. Jadi ketika pengajar di kels adalah laki-laki, maka murid perempuan tidak akan sungkem kepada pengajar tersebut., hanya murid putra saja yang sungkem.

Selanjutnyaa budaya yang taak maampu diterima sama sekali oleh mahasiswa muslim Thailand adalah norma agama Kemuhammadiyah-an yang tumbuh dan berkembang di kampus UNMUH Jember. Para mahasiswa muslim Thailand yang ada disana lebih banyak absen dalam kegiatan sholat berjamaah di 
kampus. Mereka beranggapan bahwa sholat yang dilakukan tak sesuai dengan ajaran mereka di Negara asal. Mereka yang menemui model seperti ini di Negara asal kerap memanggilnya dengan Wahabi.

\section{Metodologi}

Pendekatan penelitian ini menggunakan pendekatan kualitatif. Metode kualitatif adalah, metode penelitian yang digunakan untuk meneliti pada kondisi obyek yang alamiah dimana peneliti adalah sebagai instrumen kunci. ${ }^{13}$ Jenis Penelitian ini menggunkan studi fenomenologi. Kuswarno dalam bukunya menyebutkan bahwa Fenomenologi berusaha mencari pemahaman bagaimana manusia mengkonstruksi makna dan konsep penting dalam kerangka intersub yektivitas (pemahaman kita mengenai dunia dibentuk oleh hubungan kita dengan orang lain). ${ }^{14}$ Karena penelitian ini adalah penelitian fenomenologi yang mencoba mencari esensi makna dari suatu fenomena, peneliti terjun langsung kelapangan untuk mengamati dan menganalisis fenomena yang terjadi pada mahasiswa muslim Thailand dalam proses komunikasi antarbudaya dan proses akulturasi budaya. Mahasiswa yang menjadi obyek penelitian dalam penelitian ini adalah mahasiswa muslim Thailand yang melakukan studi di Universitas Jember, Universitas Muhammadiyah Jember, dan Institut Agama Islam Negeri Jember.

Lokasi tepatnya penelitian pertama di Institut Agama Islam Negeri Jember yang berlokasi di Jl. Mataram No.1, Karang Miuwo, Mangli, Kec.Kaliwates. perguruan tinggi selanjutnya yaitu Universitas Negeri Jember yang berlokasi di Jl. Kalimantan No.37, Krajan Timur, Sumbersari, kec.Sumbersari. dan perguruan tinggi terakhir sebagai tempat penelitian adalah Universitas Muhammadiyah Jember yang berlokasi di Gumuk Kerang, Karang Rejo, Kec. Sumbersari.

Sumber data yang digunakan peneliti dalam penelitian ini adalah melalui studi pustaka, dan berbagai sumber data dan referensi yang teoritisdan relevan denganpenelitian yang sedang diteliti seperti melalui wawancara, catatanlapangan, dan observasi. yang alamiah dimana peneliti adalah sebagai instrumen kunci. ${ }^{15}$ Jenis Penelitian ini menggunkan studi fenomenologi. Kuswarno dalam bukunya menyebutkan bahwa Fenomenologi berusaha mencari pemahaman bagaimana

\footnotetext{
${ }^{13}$ Sugiyono Metode Penelitian Kuantitatif... hal.1

${ }^{14}$ Engkus Kuswarno, Metodologi Penelitian Komunikasi Fenomenologi Konsepsi, Pedoman, dan Contoh Penelitian. (Bandung : Widya Padjajaran, 2009) hal.02

${ }^{15}$ Sugiyono Metode Penelitian Kuantitatif... hal.1
} 
manusia mengkonstruksi makna dan konsep penting dalam kerangka intersub yektivitas (pemahaman kita mengenai dunia dibentuk oleh hubungan kita dengan orang lain). ${ }^{16}$ Karena penelitian ini adalah penelitian fenomenologi yang mencoba mencari esensi makna dari suatu fenomena, peneliti terjun langsung kelapangan untuk mengamati dan menganalisis fenomena yang terjadi pada mahasiswa muslim Thailand dalam proses komunikasi antarbudaya dan proses akulturasi budaya. Mahasiswa yang menjadi obyek penelitian dalam penelitian ini adalah mahasiswa muslim Thailand yang melakukan studi di Universitas Jember, Universitas Muhammadiyah Jember, dan Institut Agama Islam Negeri Jember.

Lokasi tepatnya penelitian pertama di Institut Agama Islam Negeri Jember yang berlokasi di Jl. Mataram No.1, Karang Miuwo, Mangli, Kec.Kaliwates. perguruan tinggi selanjutnya yaitu Universitas Negeri Jember yang berlokasi di Jl. Kalimantan No.37, Krajan Timur, Sumbersari, kec.Sumbersari. dan perguruan tinggi terakhir sebagai tempat penelitian adalah Universitas Muhammadiyah Jember yang berlokasi di Gumuk Kerang, Karang Rejo, Kec. Sumbersari.

Sumber data yang digunakan peneliti dalam penelitian ini adalah melalui studi pustaka, dan berbagai sumber data dan referensi yang teoritisdan relevan denganpenelitian yang sedang diteliti seperti melalui wawancara, catatan lapangan, dan observasi.

\section{Model Komunikasi Antarbudaya Mahasiswa Muslim Thailand dalam Proses Akulturasi Budaya di Kabuapaten Jember}

Penelitian ini merujuk pada model komunikasi antarbudaya yang ditawarkan oleh William B. Gudykunts, yang mana Para mahasiswa muslim Thailand dalam proses komunikasi dapat berperan sebagai receiver dan sekaligus berperan sebagai sender. Hal ini dikarenakan dalam model komunikasi William B. Gudykunts menunjukkan bahwa masing masing dari para mahasiswa muslim Thailand dan masyarakat pribumi memiliki posisi yang sama.

Menurut model komunikasi William B. Gudykunts ada beberapa faktor yang mempengaruhi dalam proses komunikasi antar budaya diantaranya:

a) Budaya yang mencakup sosio budaya dan psiko budaya

\footnotetext{
${ }^{16}$ Engkus Kuswarno, Metodologi Penelitian Komunikasi Fenomenologi Konsepsi, Pedoman, dan Contoh Penelitian. (Bandung: Widya Padjajaran, 2009) hal.02
} 
Antara mahasiswa muslim thailand yang ada di Jember dan masyarakat pribumi, memiliki latar belakang budaya yang melekat. Ada tujuh unsur keudayaan yang diperhatikan peneliti dalam penelitian ini. Hal ini mengambil pendapat Koetjaningrat yang mengatakan bahwa ketujuh unsur ini adalah unsur kebudayaan yang bersifat universal dan dapat di temukan pada budaya semua bangsa yang ada disegala penjuru dunia. Ketujuh unsur tersebut ialah :

(1) Sistem Bahasa

Mahasiswa muslim Thailand yang berkuliah di UNEJ dan UNMUH mendapatkan kursus kebahasaan selama kurang lebih 3 bulan. Dalam kursus itu mereka diajarkan bagaimana menggunakan bahasa yang mudah dimengerti oleh masyarakat pribumi yang ada di Jember. Sedangkan untuk mahasiswa muslim Thailand yang berkuliah di IAIN Jember diwajibkan untuk masuk asrama kampus selama satu tahun penuh. Di asrama tersebut, para mahasiswa berbaur dengan mahasiswa pribumi. Hal ini dimaksudkan agar para mahasiswa dengan mudah beradaptasi dan hidup berdampingan dengan masyarakat pribumi.

Dalam setahun, mahasiswa muslim Thailand sudah mampu berbahasa Indonesia dengan baik, namun dalam berbahasa daerah seperti Madura dan Jawa, para mahasiswa hanya mampu mengerti namun sedikit kesulitan dalam mengucapkan. Para mahasiswa mencari jalan aman dengan selalu berkomunikasi dengan menggunakan bahasa Indonesia. Namun ada beberapa istilah yang mulai sering digunakan oleh para mahasiswa Thailand dalam berkomunikasi dengan masyarakat pribumi yang ada di Jember.

(2) Sistem pengetahuan

Mahasiswa muslim Thailand sangat menyukai proses belajar mengajar yang diterapkan di Indonesia terutama di kampus mereka yang berada di Jember. Jika di Thailand para mahasiswa lebih sering mendengarkan penjelasan para dosen, di Indonesia mahasiswa muslim Thailand dihadirkan dengan system pendidikan yang lebih banyak menggunakan diskusi sebagai bahan pengajaran di kelas. Para dosen hanya memantau dan membenarkan mahasiswa jika arah diskusi sudah mulai bergeser dari arah seharusnya. Dalam diskusi ada yang bertanggung jawab 
yang mendapatkan tugas presentasi dari dosen. Tugas presentasi ini diberikan untuk melatih kemampuan mahasiswa tampil di depan umum.

(3) Sistem Sosial

Salah satu hal yang menjadi catatan penting mahasiswa Thailand adalah bagaimana orang Jember bersikap terhdap para tokoh agama, kiai atau ustad. Jika di Thailand mereka memperlakukan para kiai atau pemuka agama sama dan setara dengan bagaimana mereka berbicara kepada orang tua pada umumnya, namun di Jember mereka harus belajar menundukkan bahu dan pandangan juga menjaga nada dalam berbicara kepadaa para tokoh agama atau kiai. Begitu juga dengan kebiasaan menunjuk. Bila di Thailand mereka dalam menunjuk menggunakan telunjuk baik yang diajak berbicara sebaya, lebih kecil, maupun lebih tua, di Jember mereka harus membiasakan diri untuk menunjuk menggunakan ibu jari sebagai tanda penghormatan kepada yang lebih tua.

(4) Sistem Peralatan Hidup dan Tekhnologi

Di Jember mahasiswa muslim Thailand masih sering menemukan alat transportasi tradisional yakni becak. Hal ini sangat menarik dan unik menurut mereka. Mereka mengagumi para tukang becak yang seakan tidak peduli dengan pesatnya arus perkembangan tekhnologi saat ini. Karena keunikan itu, tak jarang para mahasiswa menggunakan jasa para tukang becak untuk sekedar berangkat ke kampus.

(5) Sistem Mata Pencaharian Hidup

Salah satu kebiasaan yang dimiliki oleh para mahasiswa adalah nongkrong atau ngopi. Sehingga tak heran di jember banyak sekali tersedia tempat nongkrong atau café-café. Mulai dengan harga murah sampai harga yang relatif mahal. Para mahasiswa suka sekedar berdiskusi di café atau bahkan sampai mengerjakan tugas. Karena terinspirasi oleh hal tersebut, beberapa mahasiswa IAIN Jember membuka tempat nongkrong yang disebut dengan Menu_thai Tea. Tempat nongkrong ini dibuka mulai pukul 13.0023.00 WIB. Menu yang disediakan adalah menu minuman khas Negara mereka. Meskipun banyak di jember yang menjual thai tea, menurut mereka rasanya tidak sama dengan the Thailand sesungguhnya. Mereka mencoba mengenalkan cita rasa dari the Thailand sesungguhnya melalui tempat 
nongkrong tersebut. Bahan-bahan utama khusus didatangkan dari Thailand, jadi kemurnian the Thailand asli bisa dirasakan.

Meski awal-awal para mahasiswa tidak bisa memakan makanan yang dijual di Indonesia, namun lambat laun mahasiswa muslim Thailand mulai terbiasa untuk merasakan cita rasa kuliner Indonesia khususnya kulinerkuliner yang tersebar di daerah Jember. Bahkan kini mereka memiliki makanan favorit yang kelak akan mereka rindukan ketika kembali ke Negara asal. Ada tiga jenis makanan yang kini menjadi primadona bagi masyarakat muslim Thailand diantaranya bakso, soto, dan pecel.

(6) Sistem Religi

Mahasiswa muslim Thailand adalah mahasiswa yang cukup religius. Para mahasiswa muslim thiland yang laki-laki cukup sering mendatangi masjid-masjid yang paaling dekat dengan rumah kontrakan mereka untuk melaksanakan sholat berjamaah. Disamping itu mereka juga aktif mengikuti kajian-kajian keagamaan yang diadakan di kampus. Ketika bulan Ramadhan tiba, disamping tarawih di masjid, para mahasiswa juga melaksanakan tarawih sendiri di kontrakan mahasiswa. Dalam pengajaran keagamaan, para mahasiswa Thailand mulai banyak memahami aliran-aliran yang tersebar di bumi Jember seperti seperti NU dan Muhammadiyah. Yang dirasa sesuai dengan pengajaran yag di dapat di Thailand adalah ke-NUan.

(7) Kesenian

JFC adalah kesenian yang sangat menarik bagi mereka, setiap ada event-event JFC, para mahasiswa muslim thailand ikut bergabung dan bedesak-desakan di alun-alun jember untuk melihat parade busana yang menampilkan busana khas Indonesia. Mereka takjub dengan kemampuan orang indnonesia dalam merangkai pakaian yang begitu indah dan sarat akan kebudayaan.

Di kampus para mahasiswa muslim Thailand juga bnyak dikenalkan budaya-budaya khas yang dimiliki oleh Indonesia diantaranya pencak silat, tarian jaran kencak, dan can macanan kadhuk. Bahkan ada sedikit kemiripan antara budaya Indonesia dengan budaya Thailand dalam hal pencak silat. Para mahasiswa muslim Thailand ada yang tergabung dalam kegiatan ekstra kulikuler pencak silat di kampus meskipun hanya beberapa bulan saja. 
b) Lingkungan

Salah satu unsur yang melengkapi teori model komunikasi antar budaya milik Gudykunts adalah lingkungan. Lingkungan sangat berpengaruh dalam proses penyandian dan penyandian balik pesan. Jember adalah kabupaten yang memiliki cukup banyak perguruan tinggi sehingga Susana yang tercipta adalah suasana kampus yang dihuni oleh para mahasiswa yang datang dari berbagai penjuru daerah.

Para mahasiswa muslim Thailand mengontrak rumah yang berada disekitar kampus. Disekitar kampus terdapat banyak warung-warung makan dan café. Hal ini dikarenakan kondisi mahasiswa yang senang mengerjakan tugas atau hanya sekedar nongkrong di kafe. Selain itu para mahasiswa juga banyak yang memiliki kesibukan sehingga warung makan adalah solusi terbaik bagi mereka yang tidak sempat memasak.

\section{Komunikasi Antarbudaya Mahasiswa Muslim Thailand dalam Menghadapi Budaya Dominan di Kabupaten Jember}

Mahasiswa muslim Thailand ketika pertama kali dating ke Jember mengalami gegar budaya. Gegar budaya ini dialami karena masuknya budaya baru dalam kehidupan mereka dan menimbulkan suatu kecemasan. Kecemasan ini dialami hingga menimbulkan beberapa efek seperti sulit makan, diare, bahkan keinginan untuk pulang ke kampung halaman.

Dalam kasus gegar budaya mahasiswa muslim Thailand mengalami 4 fase yang digambarkan seperti kurva U. Fase pertama yang dialami oleh mahasiswa muslim Thailand adalah Fase optimistik. Fase ini berisi kegembiraan, rasa penuh harapan, dan euphoria sebagai antisipasi individu sebelum memasuki budaya baru. Para mahasiswa muslim Thailand sangat antusias sebelum mereka tiba di Indonesia. Belajar di luar ngeri adalah salah satu hal yang patut dibanggakan. Mendengar cerita daripara alumni mengenai betapa menariknya Indonesia terlebih Jember membuat para mahasiswa tidak sabar untuk segera tiba di Indonesia.

Selanjutnya, mahasiswa muslim Thailand mengalami Fase kultural, fase kedua dimana masalah baru dengan lingkungan mulai berkembang, misalnya karena kesulitan bahasa, system lalu lintas baru, sekolah baru, dll. Fase ini biasanya ditandai dengan rasa kecewa dan ketidakpuasan. Orang menjadi bingung dan tercengang 
dengan sekitarnya, dapat menjadi frustasi, mudah tersinggung, bersikap permusuhan, mudah marah, tidak sabaran, dan bahkan menjadi tidak kompeten

Banyak budaya yang berkembang di kabupaten Jember yang jarang mereka temui di Negara asal mereka. Bukti nyata adalah bagaimana pergaulan di kampus. Para mahasiswa di kampus terkadang setiap bertemu antara laki-laki dan perempuan masih saling melakukan salam jabat tangan. Begitupun dengan dosen mereka. Sedang di Thailand hal tersebut adalah hal yang sangat tabu untuk dilakukan oleh kalangan muslim melayu. Selanjutnya para pedagang di sekitar kampus dan juga yang berada di Jember banyak yang tidak menggunakan hijab namun makanan yang dijual halal dimakan. Sedangkan setahu mereka di Thailand bila ada pedagang yang tidak berpakaian muslimah dan tidak menggunakan hijab maka sudah dapat dipastikan penjual itu menjual makanan yang tak halal.

Bahasa juga menjadi kendala utama bagipara mahasiswa muslim Thailand dimana banyak bahasa yang berkembang di bumi Jember. Bahasa Madura dan Jawa adalah bahasa mayoritas yang digunakan oleh orang Jember. Paramahasiswa mulai kebingungan jika di kampus diajak berbicara menggunakan bahasa tersebut. Bahkan tak jarang para dosen juga melontarkan guyonan dengan menggunakan bahasa daerah tersebut. Hal ini sedikit membuat para mahasiswa muslim frustasi.

Dalam hal makanan mahasiswa muslim Thailand juga mengalami kesulitan dalam beradaptasi. Makanan Thailand terbiasa dengan rasa asin dan kecut, ketika merasakan masakan Indonesia para mahasiswa merasa makanan terasa sangat hambar. Bahkan mereka mengalami diare dan demam karena tidakcocok dengan sajian makanan yang ada di Jember.

Selanjutnya mahasiswa muslim Thailand mengalami Fase recovery, fase ketiga dimana orang mulai mengerti mengenai budaya barunya. Pada tahap ini, orang secara bertahap membuat penyesuaian dan perubahan dalam menanggulangi budaya baru.

Mahasiswa muslim Thailand berusaha mengatasi gegar budaya yang mereka alami dengan banyak bertanya kepada para senior yang sudah lebih dulu tiba di Jember. Lambat laun mereka mulai bisa menikmati dan hidup dengan dua budaya yang berdampingan. Para mahasiswa muslim Thailand membuat sebuah aturan yakni pantang pulang sebelum dua tahun berada di Jember. Sebelum masa dua tahun itu para mahasiswa berusaha untuk tidak kembali ke kampung halaman kecuali jika 
terjadi sesuatu yang sangat mendesak yang mengharuskan mereka kembali ke kampung halaman. Hal ini dimaksudkan agar mereka bisa cepat beradaptasi dan mengatasi gegar budaya yang dialami.

Dalam hal makanan, para mahasiswa mulai memasak untuk menanggulangi diare yang mereka alami. Lambatlaun mereka mulai setahap demi tahap untuk mencoba menyesuaikan lidah mereka dengan makanan dan selera orang Jember.

Terakhir, mahasiswa muslim Thailand masuk pada Fase penyesuaian, fase terakhir pada puncak kanan U. orang mulai mengerti elemen budaya barunya (nilainilai, adaptasi khusus, pola komunikasi, keyakinan,dll). Kemampuan untuk hidup dalam dua budaya yang berbeda biasanya juga disertai dengan rasa puas dan menikmati.

Pada fase ini mahasiswa muslim Thailand sudah mulai bisa menggunakan beberapa istilah yang sering digunakan dalambahasa Madura, Jawa dan bahasa slank Indonesia, seperti merka mulai sering menggunakan kata "mbak" dan "mas" untu memanggil, menggunakan kata "nggeh" untuk mengisyaratkan arti "iya". Bahasa slank yang sering digunakan adalah kata "santuy”, "siap”, “OTW”, dan masih banyak lagi. Namun jika terhadap sesama mahasiswa muslim Thailand, mereka tetap menggunakan bahasa melayu Thailand untuk tetap menjaga kelestarian budaya asli mereka.

Mengenai kuliner, para mahasiswa muslim Thailand mulai menjajaki segala macam kuliner yang tersebar di bumi Jember. Ada beberapa yang mulai digemari oleh mereka namun mereka tetap memasak. Makanan yang dimasak adalah makanan khas Thailand. Bahkan ketika bulan Ramadhan, para mahasiswa Thailand melalui organisasi HMPI mengadakan kegiatan safari kuliner dengan menjual berbagai macam makanan khas Thailand. Kegiatan itu dilaksanakan untuk mengobati rasa rindu mereka akan kampong halaman, disamping itu kegiatan ini juga dimaksudkan untuk mengenalkan kuliner asli Thailand kepada masyarakat sekitar. Menu-menu yang dijual adalah Cha-khiyaw (thai tea), Cha-yen (green tea), Mama' (mie kari), Roti Maryam, Roti Canai, dan Puluk Ayam (nasi ketan dengan lauk ayam goreng).

Selanjutnya untuk bertahan di dalam budaya yang dominan sedang budaya yang di bawa mahasiswa muslim Thailand adalah budaya minoritas, para mahasiswa 
muslim Thailand mengadakan kegiatan melaluiorganisasi HMPI agar budaya mereka tetap lestari dan bahkan untuk mengenalkan budaya mereka kepada orang Jember.

Selain kegiatan-kegiatan keorganisasian yang dilakukan mahasiswa muslim Thailand dalam mempertahankan identitas di tengah budaya dominan adalah dengan tetap menjaga kultur budaya asli tanpa harus menyinggung budaya dominan yang berkembang di Jember. Sedangkan jika ada budaya dominan yang baik maka akan mereka tiru. Sebagai contoh dalam segi berpakaian, para mahasiswa muslim Thailand putri mempertahankan cara berpakaian mereka karena dirasa lebih nyaman. Sedangkan untuk mahasiswa Thailand yang putra mereka mulai bisa menerima gaya berpakaian orang Indonesia terutama di Jember, namun tetap pada batas-batas ketentuan syar'I mereka.

Hal penting yang harus tetap mereka jaga adalah kekompakan dalam tubuh mahasiswa muslim Thailand. Hal ini untuk tetap menjaga eksistensi mereka di bawah budaya dominan. Jika kekompakan mampu dijaga, maka segala hal dapat mereka lakukan. Untuk menjaga kekompakan kelompok, mahasiswa muslim Thailand melakukan banyak kegiatan seperti tradisi Sukan Warna, wisata umum, dan halal bi halal di hari nan fitri. Tradisi Sukan Warna adalah tradisi para masyarakat melayu di Thailand. Di Jember, para mahasiswa muslim Thailand tetap melaksanakan tradisi tersebut. Pekan Sukan Warna diadakan untuk mempererat tali silaturahmi diantara para mahasiswa muslim Thailand yang tersebar dikabupaten Jember. Juga untuk mengasah bakat dan minat dalam bidang olahraga. Para mahasiswa yang tersebar di jember di bentuk kelompok kelompok dengan diberi label dan pakaian yang khas warna. Biasanya warna yang digunakan adalah biru, merah, dan hijau. Setelah dibentuk kelompok, mereka beradu tanding dalam bidang olahraga.

\section{Hasil Penelitian}

Model komunikasi mahasiswa muslim Thailand dalam proses akulturasi di kabupaten Jember, para mahasiswa melakukan berbagai proses adaptasi dengan budaya yang berkembang dikabupaten jember. Adaptasi yang dilakukan meliputi tujuh unsur kebudayaan universal. Butuh waktu sekitar satu tahun bagi mahasiswa muslim Thailand untuk dapat beradaptasi dan mengakulturasikan budaya melayu Thailand dengan budaya pandhalungan yang ada di Jember. 
Adapun komunikasi mahasiswa muslim Thailand dalam menghadapi budaya dominan yang ada dikabupaten Jember dengan terlebih dahulu mengalami proses gegar budaya. Proses gegar budaya adalah proses dimana para mahasiswa mengalami perbenturan budaya baru yang berbeda dengan budaya asli yang dimiliki. Melalui 4 fase, para mahasiswa muslim Thailand sudah mampu hidup berdampingan dengan budaya dominan. Selain itu, para mahasiswa dalam mempertahankan eksistensi kebudayaan asli yang dimiliki, membentuk berbagai kegiatan melalui organisasi HMPI dan IMASEJ. Salah satu peraturan yang wajib ditaati oleh mahasiswa muslim Thailand dalam rangka hidup berdampingan dengan budaya dominan di kabupaten Jember adalah dengan tidak pulang ke kampung halaman sebelum dua tahun berada di Jember. Jangka dua tahun dirasa cukup bagi mahasiswa muslim Thailand untuk belajar budaya Jember dan bagaimana mengakulturasikannya pada kehidupan sehari-hari.

\section{KESIMPULAN DAN SARAN}

Berdasarkan pada fokus penelitian, paparan data, temuan penelitian, dan pembahasan, peneliti dapaat menyimpulkan terkait model komunikasi mahasiswa muslim Thailand dalam proses akulturasi di kabupaten Jember, para mahasiswa melakukan berbagai proses adaptasi dengan budaya yang berkembang dikabupaten jember. Adaptasi yang dilakukan meliputi tujuh unsur kebudayaan universal. Butuh waktu sekitar satu tahun bagi mahasiswa muslim Thailand untuk dapat beradaptasi dan mengakulturasikan budaya melayu Thailand dengan budaya pandhalungan yang ada di Jember.

Adapun komunikasi mahasiswa muslim Thailand dalam menghadapi budaya dominan yang ada dikabupaten Jember dengan terlebih dahulu mengalami proses gegar budaya. Proses gegar budaya adalah proses dimana para mahasiswa mengalami perbenturan budaya baru yang berbeda dengan budaya asli yang dimiliki. Melalui 4 fase, para mahasiswa muslim Thailand sudah mampu hidup berdampingan dengan budaya dominan. Selain itu, para mahasiswa dalam mempertahankan eksistensi kebudayaan asli yang dimiliki, membentuk berbagai kegiatan melalui organisasi HMPI dan IMASEJ. Salah satu peraturan yang wajib ditaatioleh mahasiswa muslim Thailand dalam rangka hidup berdampingan dengan budaya dominan di kabupaten Jember adalah dengan tidak pulang ke kampong 
halaman sebelum dua tahun berada di Jember. Jangka dua tahun dirasa cukup bagi mahasiswa muslim Thailand untuk belajar budaya Jember dan bagaimana mengakulturasikannya pada kehidupan sehari-hari.

Dari hasil penelitian yang berjudul "Komunikasi Antarbudaya Mahasiswa Muslim Thailand dalam Proses Akuturasi Budaya di Kabupaten Jember " peneliti memberikan saran kepada Organisasi HMPI cabang jember dan IMASEJ untuk tetap memaksimalkan pembinaan terhadap para mahasiswa muslim Thailand yang melakukan studi di kabupaten Jember untuk lebih memaksimalkan potensi yang dimiliki oleh mahasiswa.

Para mahasiswa muslim Thailand yang berkuliah di Jember untuk lebih aktif kembali dalam segala aktifitas kampus yang mampu memberikan banyak pengetahuan serta lebih dalam mempelajari budaya budaya pribumi yang sebenarnya sangat menarik untuk di pelajari.

Bagi peneliti selanjutnya, bahwa penelitian dengan judul "Komunikasi Antarbudaya Mahasiswa Muslim Thailand dalam Proses Akulturasi Budaya di Kabupaten Jember" masih memiliki banyak kekurangan dan perlu banyak perbaikan sebagai akibat keterbatasan waktu, sumber rujukan, metode, pengetahuan, serta ketajaman analisis yang dimiliki kelak semoga peneliti selanjutnya dapat mengkaji model komunikasi antarbudaaya mahasiswa muslim Thailand dalam proses akulturasi budaya di kabupaten Jember dalam sudut pandang lain.

\section{DAFTAR PUSTAKA}

Cahyono, Hery Bambang. 2018. Hambatan Komunikasi Antarbudaya Mahasiswa Thailand di Jember. Jurnal Ilmu Komunikai Mediakom Vol.1 No.2.

Fakhriana, Tinka. 2018. Adaptasi Budaya Pada Mahasiswa Asing Di Indonesia (Studi Fenomenologi Pada Mahasiswa Asing Di Kota Bandung). Jurnal Ilmu Komunikasi dan Bisnis Vol.4.No.1.

Koentjaningrat. 2015. Pengantar Ilmu Antropologi. Jakarta: Rineka Cipta.

Kuswarno, Engkus. 2009. Metodologi Penelitian Komunikasi Fenomenologi Konsepsi, Pedoman, dan Contoh Penelitian. Bandung : Widya Padjajaran. Liliweri, Alo. 2018. Prasangka,Konflik, dan Komunikasi Antar Budaya. Jakarta : Prenada Media Grup. 
Mulyanana, Deddy, Jalaludin Rakhmat. 2006. Komunikas Antar Budaya Panduan Berkomunikasi dengan Orang-Orang Berbeda Budaya. Bandung: PT.Remaja Rosdakarya.

Ngalimun. 2018. Komunikasi Antarbudaya. Yogyakarta: Pustaka Pelajar.

Subekti, Sadin dan Ahmad Hayyan Najikh. 2018. Dakwah di Masyarakat Penganut Ajaran Samin. Mukammil: Jurnal Kajian Keislaman. Vol. 1, No.1.

Samovar, A Larry, Richard E. Porter, dan Edwin R.McDaniel, 2010. Komunikasi Lintas Budaya. Jakarta : salemba Humanika.

Sugiyono. 2013. Metode Penelitian Kuantitatif Kualitatif dan R\&D. Bandung : Alfabeta.

Wazis, Kun. 2020. Wacana Komunikasi Pesantren di Era Revolusi Industri 4.0. IJIC: Indonesian Journal Of Islamic Communication. Vol. 3 No.1.

Htpp ://www.unej.ac.id

http://www.unmuhjember.ac.id

http://www.iain-jember.ac.id 